Article

\title{
On the Revitalized Waterfront: Creative Milieu for Creative Tourism
}

\author{
Stella Kostopoulou \\ Department of Economics, Aristotle University of Thessaloniki, Thessaloniki 54124, Greece; \\ E-Mail: kostos@econ.auth.gr; Tel.:+30-2310-996423; Fax: +30-2310-996457
}

Received: 12 September 2013 / Accepted: 13 September 2013 / Published:

\begin{abstract}
The purpose of this paper is to discuss the role of revitalized historic urban waterfronts as potential creative milieus attracting creative tourists. Waterfront redevelopment raises issues concerning an extensive range of urban planning and management perspectives, extending from space design to economic, environmental, cultural, and tourism considerations. The paper first reviews the ways in which the relationship between waterfronts and urban functions of port-cities has evolved over time, before turning to the examination of historic waterfronts' redevelopment as creative milieus to host creative industries. The agglomeration of creative industries, cultural organizations and venues, and recreational facilities in urban spaces is widely recognized to generate a dynamic urban culture attracting a new wave of "creative tourists", which do not fit to the mainstream cultural tourism behavior, and prefer to visit lively creative spaces based, not only on heritage, but also on contemporary culture. In this paper, the analysis focuses on how historic revitalized waterfronts can act as creative milieus, based on port-cities' genius loci as cosmopolitan places of intercultural communication, offering a new alternative approach to urban cultural tourism and hopefully functioning as a spin wheel for the regeneration of the urban economy.
\end{abstract}

Keywords: waterfront; redevelopment; creative; tourism; milieu

\section{Introduction}

During the past decades, port cities all over the world, following the broad changes within the post-industrial economic regime, restructured themselves to meet the new challenges and needs that arise. Among the many changes that have gained attention, was the transformation of waterfront derelict land areas to new uses, in many cases to the so-called emerging landscapes of consumption, 
such as commercial and entertainment complexes. Widespread desindustrialization, the expansion of service economy and the perspective that tourism development would result in the regeneration of urban cores, have driven different port-cities to progressively incorporate tourism activities into urban waterfront redevelopment projects [1,2].

Following the decline of old harbor sites and industrial areas in many port cities all over the world, in the second half of the 20th century there has been an intense effort to redesign abandoned waterfronts. Starting in North America, in the 1970s, with the success example of Baltimore's Inner Harbor project, urban waterfront revitalization has been steadily extending in many cities worldwide. In Europe, since the 80s numerous examples on different scales have been produced, ranging from the larger at London's Docklands, to smaller projects such as Canute Wharf, Southampton, to include port cities as diverse as Liverpool, Geneva, and Barcelona. Urban waterfront redevelopment projects, aiming at reintegrating abandoned harbor areas into the urban fabric, thus became an international phenomenon of urban renewal. This is reflected in a rich literature starting in the early 1980s that seeks to explain these processes from an economic, geographical, or spatial planning perspective [3-20].

Nowadays, waterfront redevelopment is a global trend and thousands of schemes are being carried out in large metropoles, medium-sized cities, and even small towns all over the world. Due to their advantageous location at the interface between built environment and water, near the city centers, waterfronts provide highly exploitable urban spaces for new uses like large-scale office, leisure and residential projects [21-23]. Whereas the early examples of historic waterfront redevelopment focused mainly on leisure and retail uses, contemporary schemes have to face complex urban development problems $[14,24,25]$. The transformation from production to service-economy, and the increased demand for cultural facilities in post-industrial cities, gradually led culture to become an increasingly important tool for waterfront regeneration. As a result, vacant warehouses and port factories have being widely used to host cultural events and amenities, making historic waterfronts more attractive for tourism and enhancing local vitality $[15,20,26]$.

However, the role that the historic built environment can play in the process of waterfront redevelopment, and how this should be integrated in urban planning, are still challenging questions for local governments in the world's numerous port cities of distinctive identity and immense diversity. How to avoid the risk of replicating spatial planning clichés [27] in search for authenticity and integrity in historic waterfront redevelopment and for the conservation of the genius loci or the "spirit of place"? How to create attractive urban waterfront environments to support "an image of a thriving city" [14] that would persuade people to work there, live there or visit the place, hopefully generating positive spin-off effects for the local economy?

Success stories of postindustrial urban economic development are in many cases based on innovative business services, creative industries, and consumption of in situ produced cultural products and intangible experiences that gradually become an important component of contemporary urban culture and production [25]. For historic port cities that have to stay competitive in a constantly evolving urban world, revitalized waterfront areas provide challenging arenas for the location of creative industries, art pioneers and cultural organizations. Even though "city branding" waterfronts [28] with mixed uses of working, living, shopping, and recreation are quite well documented in the international literature, the perspective of historic waterfronts to function as creative milieu to host 
creative industries and their potential to attract the new generation of creative tourists, while promising, are still rather underexplored.

The purpose of this paper is to examine the potential of historic revitalized waterfronts to become urban creative hubs and creative tourism attractions. The analysis will begin with a brief overview of the historical evolution of waterfronts and their changing role for the port-city. In the next section the notions of creative milieu and creative industries will be presented and their role in the regeneration of historic waterfront areas will be analyzed. The new wave of creative tourism and the potential of historic revitalized waterfronts to attract creative tourists are then explored. Finally, certain concluding remarks and issues for future research are made about the perspective of waterfront creative milieus to act as potential catalyst for the development of urban creative industries and creative tourism.

\section{Waterfronts: A Fascinating History}

Urban waterfronts, generally referred as the part of a town or city that abuts water, especially a district of wharves where ships dock, have always been places full of locational advantages, due to the concentration of interactive land and water activities [9,29-34]. Water, as a primary human resource for nourishment, irrigation, and transportation, was the raison d'être for man's earliest settlements and hence, a vital part of civilization involves events and development that have occurred along the world's coasts, rivers, bays, and lakes. Historically, port development has dominated local communities, bringing economic well-being and a cosmopolitan dimension to urban life. Ports became significant settlements based on a range of productive sectors, both within manufacturing and today's "product services", and also through the growth of a prosperous urbanist culture and society [35]. From the early fishing village, developing from a settlement close to water, to the busy transshipment stations serving the rapidly growing world transportation, up to the modern expanding logistics hubs, this development process of value-added labor, value-added production, and value-added service [29] epitomizes the diversity of ports and their significance to life, industry, and commerce [36].

The functional relationship between ports and cities, deteriorated during the 20th century, due mainly to the evolution of maritime technology and the evolving multifunctional character of post-industrial cities that gradually lessened their dependence on port activities. The changeover in international shipping practices led to the use of ever-larger ships, containerization, and more extensive stocking areas that forced ports to slowly move away from central city locations. Port closure was followed by the decline of traditional harbor and manufacturing industries that abandoned their water bound sites and moved to suburbs. The traditional harbor economy gradually lost its function as the core economic base of the urban development, involving a sharp reduction in number of local workforce, depopulation and urban dereliction. Dock areas in historic waterfronts gradually degenerated from symbols of prosperity into symbols of economic and social decay [33,37,38].

However, as Ashworth [7] points out, the discard of the waterfront by port and associated activities, together with the area's previous likely historical significance, resulted in the survival of architectural relics and historic associations. The resulting "zone of discard" [39] located at or adjacent to the city center and involving the land/water interface, endowed urban waterfronts with potentially high quality natural and built environments from which stem inherent virtues exploitable as resources of urban tourism. As a consequence of the maritime economy changes, formerly busy, but then under-used, physically 
deteriorated port areas, had to re-adjust their uses so as to regain their economic and social links with the city and reinforce urban economic growth [3] (Figure 1). Within the context of sustainable urban development policy, waterfront restructuring, or otherwise called in the literature waterfront "redevelopment", "regeneration", "revitalization", or "rehabilitation" [32,40-42], became the focus of urban planning projects.

Figure 1. The historical model for port-city development.

(II) Expanding cityport

Source: adapted from Hoyle et al. (1988) [3].

All over the world, abandoned waterfronts have been redeveloped using a mixed-use model typically dependent on leisure activities, exclusive housing, office development and retailing. Restaurants, pubs, aquariums, leisure, retailing, festival markets, historic ships, hotels, and many related facilities have become inseparably associated with the revitalized waterfront in cities worldwide. The example of Baltimore's Inner Harbor project in the early 70s, commonly coupled with Quincy Market in Boston, as the outstanding case study of waterfront revitalisation in the United States [10], provided a successful model that has become the classic tale of modern times [13]. The so-called "Baltimore syndrome" [34] has been spreading among the world's coastal cities concerned to varying degrees with waterfront revitalisation plans. False Creek in Vancouver, Fisherman's Wharf in San Francisco, Darling Harbor in Sydney, Victoria and Alfred Harbor in Capetown, Docklands in London, and Kop van Zuid in Rotterdam are some of the international examples, within which new retailing, office, and tourism developments were combined with the reuse of historic port related buildings and the historic atmosphere of the harbor [3,8,11-13,16,39,43,44].

Baltimore's Inner Harbor project is considered to be a unique success story of business and political leadership coming together, since redevelopment was helped by a strong mayor system [10]. Historically, Baltimore has been a major U.S. seaport since the 18th century. The Inner Harbor continued to be an important manufacturing and shipping hub until 1904, when the Great Baltimore Fire destroyed the downtown and dock areas. Without the necessary improvements required to modernize dock facilities, so as to manage the shift from break-bulk to containerized shipping, the 
piers and warehouses became run-down and abandoned [45]. In the 1950s, the Inner Harbor, once a thriving commercial center, was decimated with derelict warehouses and deserted streets, surrounded by overcrowded and deteriorating neighborhoods. The city suffered from severe problems of population and precipitous economic decline, with lower incomes and higher unemployment than the rest of the metropolitan area [10]. By the 1960s, it had become apparent that Baltimore was in urgent need of a plan for reversing the decline and the leadership of the city's business community, created a Committee for Downtown to raise private funds for the preparation of a master revitalization plan.

The Greater Baltimore Committee and the Committee for Downtown agreed that downtown revitalization was a top priority and produced a redevelopment plan, which was accepted in 1959. The renewal of Baltimore's Inner Harbor area thus began with the development of Charles Center, a 33-acre office area between the existing retail and financial districts, which arose from private initiative. Over 200,000 square meters of office buildings, 40,000 square meters of retail shops, hotel, theatre, and 300 apartments were provided [10]. The success of the scheme, caused the Greater Baltimore Committee to propose, in 1964, an ambitious expansion plan of the redevelopment efforts, to include the adjacent Inner Harbor area and re-use the maritime waterfront for tertiary facilities, and middle-class and tourist settlements [34], with the key element being to bring the public to the water's edge. The plan included four primary goals: reconstruction of the Municipal Center; construction of office buildings on "prestigious" waterfront sites; multi-family housing along the east and west sides of the Harbor; and a waterfront "playground" to serve as a center of recreation, culture, and entertainment for the local population [46].

In 1968, with the property along the water's edge in public ownership, a new bulkhead/public wharf was built, followed by a public promenade circling the Harbor to connect public recreation areas, picnic shelters, and play areas, while open spaces were minimally landscaped to allow for a variety of uses $[45,46]$. The city began promoting the waterfront area as a place for free entertainment and recreation activities with the introduction of "Sunny Sundays" promenades and weekend cultural events. Meanwhile, large corporations begun committing to the construction of large office towers along the Inner Harbor, the World Trade Center was approved, and plans for a marina and finger piers were underway.

In 1973, the Baltimore City Fair drew 1.5 million people to the harbor over one weekend, with festivals and other activities held at the water's edge [45]. The U.S. Constellation, the oldest surviving navy warship, was anchored in the Inner Harbor, becoming its first attraction and a symbol for Baltimore. City officials and harbor managers began to envision the Inner Harbor as an international tourist destination. In 1979, the Baltimore Convention Center opened, followed shortly by the opening of James Rouse's Harborplace, a festival marketplace that proved to be a great success, putting the city into the top tourist league: within two to three years of opening it had 18 million visitors a year [10]. Together with Science Center, the National Aquarium and the Hyatt Regency Baltimore Hotel, the Inner Harbor soon reached its critical mass of attractions.

In the mid-1990s the Camden Yards Sports Complex was constructed, comprising the Oriole's baseball stadium, Ravens football stadium, the converted old Camden rail station, warehouse, and office building, museums, stores, and restaurants. By 2000, sixty new projects had been completed in the Inner Harbor area, including twelve hotels and a subway station, while the eastern area of the Inner Harbor has been developed with residential buildings, retail shops, restaurants, and hotels [46]. 
Attractions such as the American Visionary Art Museum, the renovated mixed-use Power Plant building, and the nightclub and entertainment center Power Plant Live! attract residents and tourists to this thriving area. Baltimore's Inner Harbor, transformed from neglected backwater into a vital part of the city, has proven to be an aesthetic and economic success that stood rather successfully the test of time, characterized by the American Institute of Architects as "one of the supreme achievements of large-scale urban design and development in U.S. history" [46] (Figure 2).

Figure 2. Baltimore's Inner Harbor.

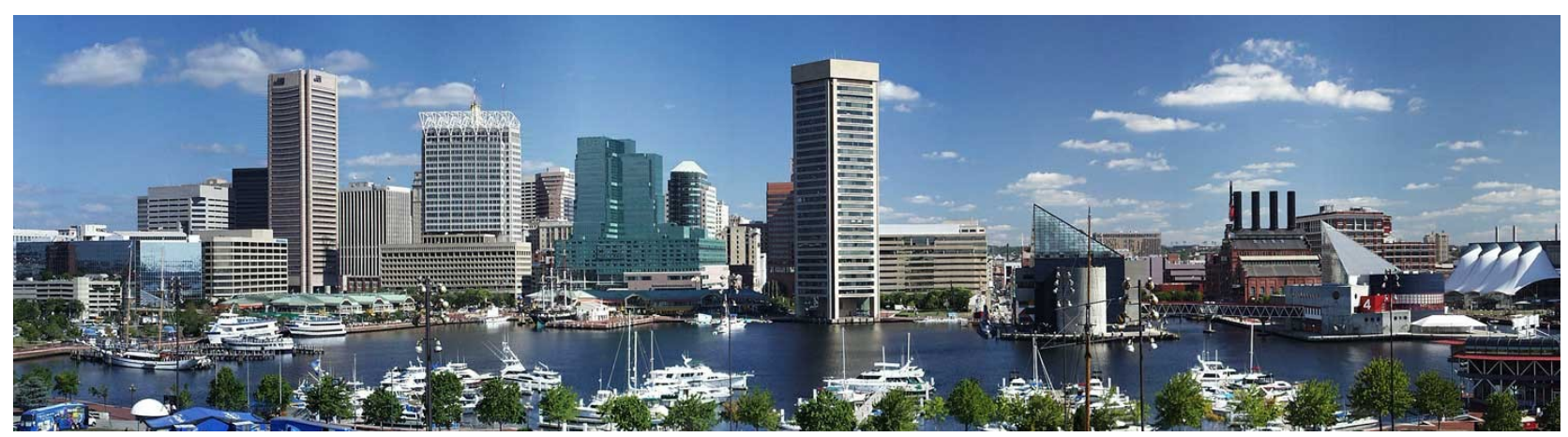

Source: Baltimore Inner Harbor Panorama from Federal Hill Park (overlooking the harbor) [47].

In the international literature, many classification methods of the process of waterfront development have been introduced. Breen and Rigby [13] assign redeveloped waterfronts into six distinct groups based on development modes: commercial, cultural educational and environmental, historic, recreational, residential, and working. Vallega [34] classified waterfront by activity, proposing twelve activities: ecosystem enjoyment, fishing, tourism, recreation, entertainment, congresses, media, transport and navigation, trade and finance, research areas, education and training, and cultural heritage. Waterfront development taking into consideration the preferences of the community can also be grouped, indicatively though not exhaustively [40], into the following categories $[16,18,33,42,48]$ : entrepreneurial (corporate activities, businesses, banks, and insurance), popular leisure (leisure, sports, and sea activities), residential (luxury housing districts), environmental (land parks, walkways, aquariums, ecological, and marine parks), high-culture (theatres and historic buildings), and commercial (shopping centers, conference facilities, and business districts).

Yet, this worldwide waterfront restructuring process, to overcome the marginalized image of harbor areas, confronts coastal city planning with many challenging problems. In many cases urban waterfronts have developed a tendency towards similarity, in terms of the mixed-use elements they contain [44]. This tendency, caused mainly by the economic-oriented exploitation of the port areas can lead, at an extreme case, to the creation of "non-places" like leisure parks, commercial, and entertainment complexes. At the other extreme, a "mono-thematic" culture-dependent approach to waterfront development, can lead to the creation of social "elite" cultural areas. Therefore, a compromise choice, in which the existing built, natural, historical, and cultural qualities of the area are integrated with the practicalities of social change and economic development seems to be a major challenge in planning decisions for historic waterfront development. A balanced complementarily of functions, with the presence of residents, "knowledge workers", shoppers, and spectators in a 
multifunctional waterfront hosting shops, parks, entertainment, museums, and historic heritage, keeps harbor areas lively all the time, a prerequisite for successful waterfront development $[24,25,49]$.

The competition for waterfront space and the conflicting interests of the various stakeholders involved, including the need for public access to the shore and places "for all" thus became topical issues in urban policy literature [30,50]. Within the context of the aspirational move from the city as capital of culture, emerging in the late 1980s/1990s [51], towards a creative city [52], the question whether historic revitalized waterfronts can shift from singular cultural brands [53] to creative milieu based on diversity, experimentation but also on the "spirit of place" now forms a tempting subject in urban analysis.

\section{Waterfronts as Creative Milieus}

Charles Landry ([52], p. 133) defined creative milieu as "a place - either a cluster of buildings, a part of a city, a city as a whole or a region - that contains the necessary preconditions in terms of "hard" and "soft" infrastructure to generate a flow of ideas and inventions". By "soft infrastructure" usually a system of associative structures and social networks is denoted (e.g., organizations, business clubs, think tanks, public-private partnerships), connections and human interactions that underpin and encourage the flow of ideas between individuals and institutions. Whereas the "hard infrastructure" is considered as a nexus of buildings and institutions such as educational and research institutions, cultural facilities and social meeting places (e.g., cafes, bars) as well as support services such as public transport, health, and amenities (e.g., public places, parks, sports facilities) [28]. Evans [54] evokes that Richard Florida's reworking of the "Creative Class" [55,56] can also be viewed as a postindustrial version of the cultural milieu which has ever been evident in the heyday of culture cities [21]. Spatially this has been represented in terms of cluster theory introduced by Porter [57,58] but harking back to Alfred Marshall's [59] economic theory of industrial agglomeration.

Due to the growing interest in culture and the increased popularity of artistic environments in post-industrial societies, creative milieus, as urban agglomerations of creative and cultural activities, are widely recognized to play an important role to a city's attractiveness for tourism and inward investment. Worldwide, creative milieu come into existence usually in deprived, derelict areas, such as harbor abandoned zones and factory complexes $[60,61]$ that provide ample space to new pioneer, informal uses. The use of waterfront vacant infrastructure by the new hybrid of artists and entrepreneurs, the so-called culturepreneurs [28], e.g., can affirm a new or different appreciation of the built environment, creating a new product for cultural consumption. Cable Factory in Helsinki and Spike Island in Bristol (Figures 3 and 4) are two successful examples of how the opening-up of harbor areas to new experimental uses may act as a catalyst to waterfront redevelopment, stimulating the settlement of creative industries that can generate potential positive economic, social, and cultural spin-off effects for the wider urban community. 
Figure 3. Cable Factory, Helsinki.
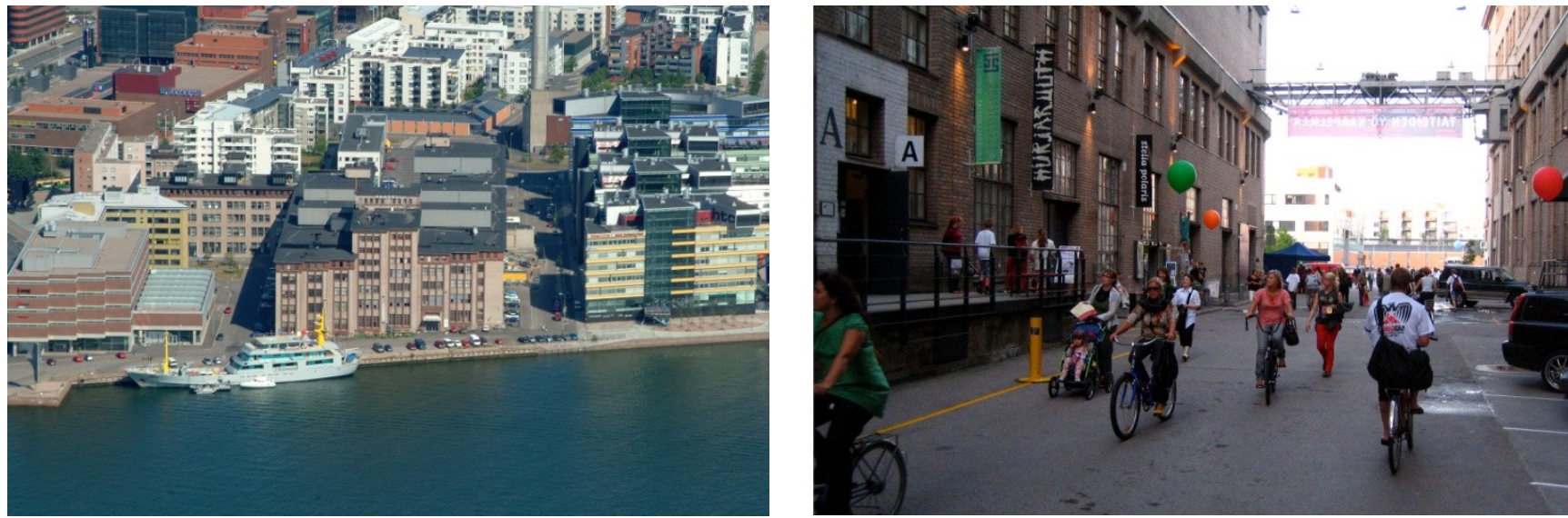

Source: INFO [62].

Figure 4. Spike Island, Bristol.
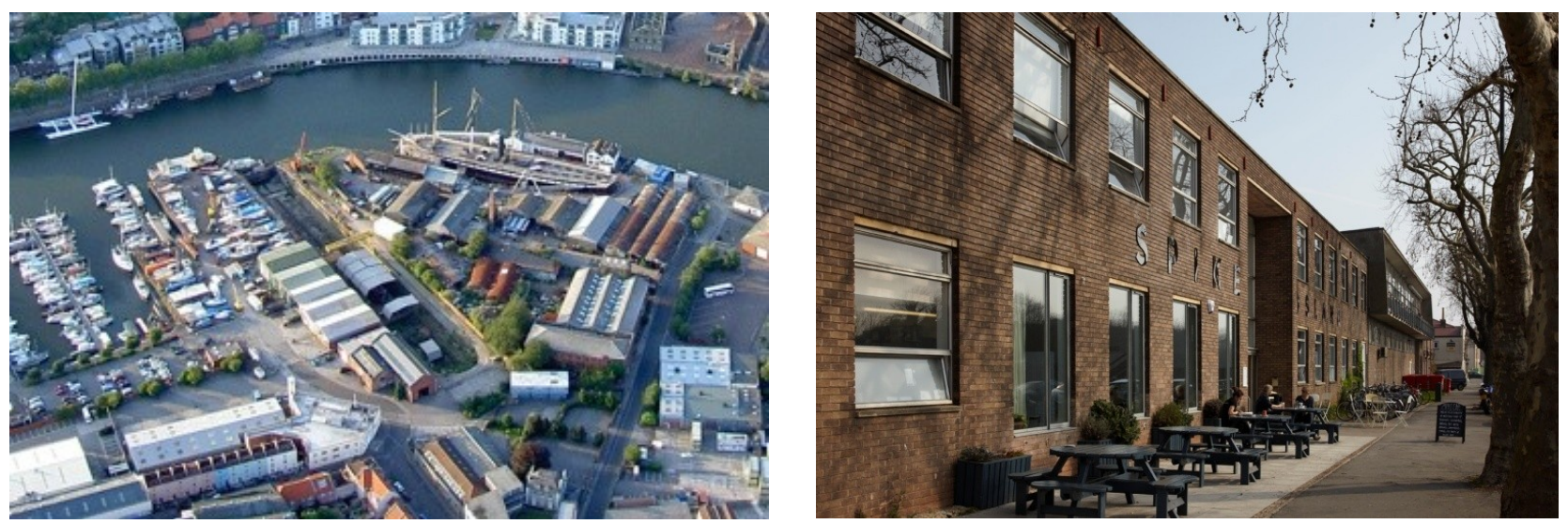

Source: Spike Island [63].

Spike Island Artspace is an international center for the production and exhibition of contemporary art and design, situated on the southern end of Bristol's historic docks (Figure 4). It is housed in a late-1950s former Brooke Bond tea packing factory of some 9,000 square metres, accommodating 70 low-cost studios, rented to artists, an exhibition gallery, facilities for fine art students at the University of the West of England (UWE), and spaces for new small businesses in the creative industries including: fine art fabrication, graphic, web, product and interactive design, typography, film and video production, illustration, and animation. Spike Island forms a major part of a vibrant hub of creative and cultural activity amongst Bristol's Harbourside community, offering visitors a year-round program of exhibitions, events, and family activities. It receives some public funding, but much of its turnover comes from rent paid by artists and business tenants.

Creative industries, even though considered as an important economic sector in post-industrial cities, are still a buzzword within urban economic analysis and policy, lacking a clear and widely accepted definition [28]. According to Landry [52] creative industries mark the convergence of artistically based industries with new communication technologies and "their cross-fertilization through digitalization". These usually include three categories of activities: performing and visual arts and crafts (fine arts and art market, museums, theatres, operas, entertainment); media and 
entertainment (music, publishing, film industry, radio/TV, multimedia); and creative business services (design, fashion design, architecture, communication). Creative industries now generate a large and steadily increasing share of employment and gross domestic product, at the local, regional and national level. Moreover, creative and cultural activity enhances a city's quality of place, helps to revitalize derelict urban areas and shapes the city's identity in an increasingly competitive urban environment. Many cities around the globe, from metropolitan centers like New York, to smaller centers like Newcastle, UK [64], recognizing the economic and social benefits that flow from the creative economy, now develop policies that give strategic priorities to creative and cultural activities.

Creative industries largely rely on their spatial agglomeration since networking, joint collaboration platforms, shared local services, and a widespread creative atmosphere often lead to positive synergies' effects, which are essential in a sector with a rather high share of small enterprises. The location of creative industries in historic revitalized waterfronts can give a new development perspective to under-used or abandoned harbor infrastructure that may stimulate the involvement of local government and potential investors. Cultural events and alternative amenities (festivals, art exhibitions and performances, public lectures and debates, bars, cafés, and design shops) and innovative business hubs (business technology services, new media firms) hosted in restored warehouses and port industries, can form a new "sense of the place", a creative cosmopolitan urban culture space to attract citizens and visitors.

However, as pointed out in the literature, creative spaces also depend on "habitus" [65,66], and therefore special attention must be paid in integrating the place's identity, showcasing its past heritage and distinctiveness. Heritage, also "a mode of cultural production" ([67], p.7), depends on display to give dying economies and dead sites a second life as exhibitions of themselves. The question of the identity of historic waterfronts as distinctive places lies at the heart of managing waterfront redevelopment. However, as Rodwell [38] pertinently indicates, much of the specific character of waterfronts involves more than cultural heritage protection, since historic harbors are not just about built environment and technical infrastructure. Having being cosmopolitan, multi-cultural, and multi-ethnic places, leading gateways for the exchange of goods and ideas, port-areas bear witness to specific multiple forms of human interaction, of business and social meeting, of exchange and communication, a unique blend of tangible and intangible cultural heritage traditions related with water. These exciting environments with a strong sense of place, are magnets for tourism, and if properly exploited, may not only bring economic benefits, but also help to consolidate the identity of the city.

Therefore, celebrating and accessing creative waterfront areas involves also the capture of the genius loci, and the ways in which citizens and visitors can interact with port environments, offering an alternative and possibly more sustainable approach to urban cultural tourism development [54]. The agglomeration effects of creative industries, arts and cultural organizations and venues, higher education and research establishments and the supporting hospitality and recreational facilities, generate a dynamic market of business, educational, and cultural tourism, also including mainstream "city break", arts and heritage tours based on waterfront cultural heritage. Moreover, waterfronts as creative milieus hosting experimental cultural activities, provide opportunities for citizens and visitors to interact with a unique urban environment in "...individual and spontaneous ways" [68] that rarely occur in conventional cultural urban spaces. This is important for waterfront areas which see the potential to diversify and develop into distinctive creative spaces attracting all-year round the new wave of creative tourism. 


\section{Waterfronts: Creative Milieus for Creative Tourism}

Tourism, widely considered by academics and practitioners to become the largest global industry, is being fueled by the steadily increasing flows of urban tourism, which is characterized as a complex phenomenon with a diverse and vaguely formulated set of activities [27,69]. Worldwide, cities gradually become cultural tourism destinations, hence to different degrees [70] depending on local factors such as the inheritance of fine buildings and history, but also on modern cultural exchange and experience, which interact to create different outcomes.

Urban cultural tourism campaigns have initially promoted the largely passive tours to performing and visual arts festivals, theatres, museums, galleries, and heritage venues. Exploiting culture for tourism became an established urban destination marketing tool worldwide including literary tourism and trails, architecture tours and branding, e.g., Gaudi Barcelona or Ethnic Festivals, e.g., Notting Hill-London [54]. However, as cultural tourism becomes more diverse but at the same time more standardized, the necessity of maintaining distinction while promoting tourism in post-industrial cities has led to a renewed process of city cultural branding [71,72]. Cities that are most successful now offer, both culture consumption and production, heritage, and contemporary culture, and a cosmopolitan urban culture not to be easily replicated [26], hopefully based on the "spirit of the place". Cities are developing local creative industries and pioneer cultural entrepreneurship in urban creative milieus that could precede "urban tourism" to attract an extensive array of rising tourism markets. The art market and design industries that initially served a commercial and "elite" world [54], following the growth of art museums and the celebration of industrial and contemporary design have been gradually brought into the tourist sphere, generating their own exclusive clientele of creative tourists.

Following the early post-war massive "sun and sea tourism", and the subsequent alternative forms and mainstream cultural tourism, the new generation of "creative tourism" involves the educational, emotional, social and participative interaction of the visitor with the place and its living culture. Creative tourism is travel directed toward an engaged and authentic experience, with participative learning in the arts, heritage, or special character of a place, and provides a connection with those who reside in this place and create its living culture [73]. Today's creative tourism includes, among others, creative business tourists like artists, designers, trade or event producers, creative product organizations and networks, critical curators, global foundations and touring blockbuster exhibitions, educational tourists like students, cultural tourists motivated by "knowledge economy transfer" or urban renovation. This new generation consumers are considered as the pathfinders of a new form of creative tourism trail [54], where independent travel gradually overtakes package tours and visitors organize themselves, leaving space for spontaneous behavior.

In order to attract these new forms of tourism cities need creative urban spaces, as Walberg [74] suggests, spaces where things are more unorganized so as not to be turned into "malls". In modern urban tourism destinations worldwide, it is outside of the walled museum and heritage site that the actively created creative spaces are to be found, where art market, design houses and experimental performances co-exist with club culture, traditional cultural events, fashion, and design fairs. The growth of trade exhibitions as cultural events is an example phenomenon which links existing creative production and cultural tourism around major city sites. Fashion Weeks combined with rock 
concerts or film festivals can generate a unique buzz, attracting media coverage and reinforcing place marketing, that only few if any tourism campaigns can generate and maintain annually [54].

This approach to urban tourism development requires that tourism managers and urban planners have also to evolve, recognize the creativity within their city as a resource, and provide new opportunities to meet the evolving interests of creative tourists [73]. There are responsibilities for both the public and private sectors. The public sector is expected to provide the necessary creative milieu and an enabling financial environment, and build synergies among the various stakeholders involved (creative industries, culturepreneurs, investors, municipality, and local community), whereas the private sector is responsible for its own self-promotion and networking around shared problems.

It is widely acknowledged that while creative tourism must be linked to culture, the particular cultural attractions are to be unique to each place. Similarly, the products of local creative industries can gain their distinctiveness and uniqueness through elements of local identity or "brand" of the milieu as a vibrant and unique "place to be" [75]. For historic port-cities continuity of the tangible (architectural) and intangible (human) cultural traditions, of their historical mixed use characteristics, the socio-economic diversity and human vibrancy that attaches to "spontaneous order" [76] are challenging questions in planning the creative waterfront redevelopment.

Historic revitalized waterfront areas and their built environment give room to different uses to develop in a creative symbiosis of cultural, everyday and commercial activities [28]. The everyday culture of the creative waterfront milieu is easily celebrated and accessed, in contrast to the conventional and in many cases environmentally unsustainable experience at touristic and heritage sites. Waterfront open-door creative spaces offer to visitors the freedom to decide if and how they want to make use of the facilities available and participate in a diversity of creative activities. Waterfronts as creative milieus hosting art galleries and design centers, cultural amenities, and creative industries, could thus act as a smart urban development strategy expected to benefit residents, culturepreneurs, and tourists, boosting the local economy and improving the urban environment and quality of life.

\section{Concluding Remarks}

This paper is motivated by the goal of contributing to the better understanding of how historic revitalized waterfronts can function as creative milieus to attract creative tourism and support the urban economy. Port-cities can strengthen their creative spaces, and, thus, their creative capacity, by preserving historic harbor areas not only to showcase their distinctive character, but also to use the waterfront built environment to accommodate creative industries. Creative and cultural activities can act as a powerful vehicle for waterfront-diversified redevelopment, not only for generating wealth and employment opportunities, but also to upgrade the image of the area and the city. Historic revitalized waterfronts as creative milieus, can thus act as catalysts for urban economic regeneration and creative tourism development, enabling citizens and visitors to reconnect with historic harbor areas not only for business, social exchange or leisure, but also to participate to creative and cultural activities.

A basic difficulty involved in waterfront redevelopment schemes is the reconciliation of the many inter-related influences, objectives and interests involved. For many urban waterfront zones improvement of the quality of urban space and urban life is a necessary intermediate step towards the restructuring of local economies and notably towards urban tourism $[15,44]$. Conventional economic appraisal of 
tourism development projects often focuses on the "measurement of the measurable" (i.e., visitors attracted, jobs created, income generated etc.). However, as Anderson and Nurick [77] argue, this does not reflect the "immeasurable" effects on the places in which these projects are located, that is the changed image and aspirations of a place and the upgraded quality of life of residents that are increasingly becoming a more and more important factor in investment and employment locational decisions.

In historic port-cities, the distinctive character of harbor areas imposes the need for creative waterfront redevelopment to incorporate an approach that re-positions urban planning as part of a continuous cultural process that embraces tangible and intangible aspects, reinforces genius loci and associative values, focusing on quality and the recovery of cultural and social dignity to the degraded parts of cities (Bruno Gabrielli as cited in [78]. As Rodwell [38] indicates, planning systems for historic port cities that conform to a regeneration typology favoring the re-invention of their waterfronts to sanitized, gentrified models, have also to address the socio-economic, cultural, and environmental issues of their cities as a whole.

Historic revitalized waterfront areas, as creative milieus form unique modern "agora" places that provide the possibility for creative uses by citizens and visitors. Within this framework, tourism exploitation of the waterfront's natural and built environment, should rather fit to the creative use of the area, while respecting the "spirit of the place" in order to create a new quality competitive image of the city. The geography of waterfront development at different regions and scales suggests that it is essential to preserve and enhance the distinctiveness of individual locations and environments [44]. For this goal to be achieved, cross-disciplinary evaluation and management tools are required to investigate the distinctive identity of individual cities, yet to be incorporated into urban waterfront planning. Within this context, a subject worthy for further research is the investigation of Mediterranean waterfronts which, due to their strong historic character and cultural heritage through the times of Greek, Roman, Arab, and Ottoman empires, do not readily admit "standard" redevelopment projects and may form a distinctive Mediterranean creative milieu profile.

\section{Conflicts of Interest}

The author declares no conflict of interest.

\section{References}

1. Cybriwsky, R. Changing Patterns of Urban Public Space: Observations and Assessments from the Tokyo and New York Metropolitan Areas. Cities 1999, 16, 223-231.

2. Pearce, D.G. An Integrative Framework for Urban Tourism Research. Ann. Tourism Res. 2001, 28, 926-946.

3. Hoyle, B.S., Pinder, D.A., Husain, M.S., Eds. Revitalising: The Waterfront: International Dimensions of Dockland Redevelopment; Belhaven: London, UK, 1988.

4. Mann, R.B. Ten Trends in the Continuing Renaissance of Urban Waterfronts. Landsc. Urban. Plan. 1988, 16, 177-199.

5. Hershman, M.J., Ed. Urban Ports and Harbour Management: Responding to Change Along U.S. Waterfront; Taylor and Francis: New York, NY, USA, 1988. 
6. Sieber, R.T. Waterfront Revitalization in Post-Industrial Port Cities of North America. City Soc. 1991, 5, 120-136.

7. Ashworth, G.J. Heritage Planning: Conservation as the Management of Urban Change; GeoPers: Groningen, The Netherlankds, 1991.

8. Hoyle, B.S., Pinder, D.A., Eds. European Port. Cities in Transition; Belhaven: London, UK, 1992.

9. Hoyle, B.S. Urban Waterfront Revitalization in Developing Countries: The Example of Zanzibar's Stone Town. Geogr. J. 2002, 168, 141-162.

10. Hall, P. Waterfronts: A New Urban Frontier. In Waterfronts: A New Frontier for Cities on Water; Bruttomesso, R., Ed.; International Centre Cities on Water: Venice, Italy, 1993; pp. 12-19.

11. Bruttomesso, R., Ed. Waterfronts: A New Frontier for Cities on Water; International Centre Cities on Water: Venice, Italy, 1993.

12. Breen, A.; Rigby, D. Urban Waterfronts: Cities Reclaim their Edge; McGraw-Hill: New York, NY, USA, 1994.

13. Breen, A.; Rigby, D. The New Waterfront: A Worldwide Urban Success Story; Thames and Hudson: London, UK, 1996.

14. Jauhiainen, J.S. Waterfront Redevelopment and Urban Policy: The Case of Barcelona, Cardiff and Genoa. Eur. Plan. Stud. 1995, 3, 3-23.

15. Craig-Smith, S., Fagence, M., Eds. Recreation and Tourism as a Catalyst for Urban Waterfront Redevelopment: An. International Survey; Praeger: London, UK, 1995.

16. Gordon, D. Managing the Changing Political Environment in Urban Waterfront Redevelopment. Urban. Stud. 1997, 34, 61-84

17. McCarthy, J. Spatial Planning, Tourism and Regeneration in Historic Port Cities. DISP 2003, 154, $19-25$.

18. Dong, L. Waterfront Development: A Case Study of Dalian China; University of Waterloo: Waterloo, Canada, 2004.

19. Hagerman, C. Shaping Neighborhoods and Nature: Urban Political Ecologies of Urban Waterfront Transformations in Portland, Oregon. Cities 2007, 24, 285-297.

20. Gunay, Z.; Dokmeci, V. Culture-Led Regeneration of Istanbul Waterfront: Golden Horn Cultural Valley Project. Cities 2011, 29, 213-222.

21. Hall, P. Cities and Civilization: Culture, Innovation, and Urban. Order; Weidenfeld and Nicholson: London, UK, 1998.

22. Fainstein, S. Mega-Projects in New York, London and Amsterdam. Int. J. Urban. Reg. 2008, 32, $768-785$.

23. Lehrer, U.; Laidley, J. Old Mega-Projects Newly Packaged? Waterfront Redevelopment in Toronto. Int. J. Urban. Reg. 2008, 32, 786-803.

24. Bender, R. Where the City Meets the Shore. In Waterfronts: A New Frontier for Cities on Water; Bruttomesso, R., Ed.; International Centre Cities on Water: Venice, Italy, 1993; pp. 32-38.

25. Romein, A. Leisure in Waterfront Redevelopment: An Issue of Urban Planning in Rotterdam? Available online: http://aesop2005.scix.net/data/papers/att/606.fullTextPrint.pdf (accessed on 27 may 2012).

26. Evans, G. Measure for Measure: Evaluating the Evidence of Culture's Contribution to Regeneration. Urban. Stud. 2005, 42, 959-984. 
27. Ashworth, G.; Page, J.S. Urban Tourism Research: Recent Progress and Current Paradoxes. Tourism Manag. 2011, 32, 1-15.

28. Breuer, S. Harbouring creative industries-Creative milieus as a catalyst for harbour regeneration. Master Thesis, Advanced Master of European Urban Cultures-Universiteit Tilburg (The Netherlands), Manchester Metropolitan University (United Kingdom), Estonian Academy of Arts (Estonia), 2006.

29. Huang, W.-C.; Chen, C.-H.; Kao, S.-K.; Chen, K.-Y. The Concept of Diverse Developments in Port Cities. Ocean. Coast. Manag. 2011, 54, 381-390.

30. Sairinen, R.; Kumpulainen, S. Assessing Social Impacts in Urban Waterfront Regeneration. Environ. Impact Asses. 2006, 26, 120-135.

31. Breen, A.; Rigby, D. Caution: Working Waterfront-the Impact of Change on Marine Enterprise; The Waterfront Press: Washington, DC, USA, 1985.

32. Goodwin, R.F. Redeveloping Deteriorated Urban Waterfronts: The Effectiveness of US Coastal Management Programs. Coast. Manag. 1999, 27, 239-269.

33. Hoyle, B. Revitalizing the Port-City Waterfront: Retrospect and Prospect. Geogr. Rev. 2000, 90, 395-417.

34. Vallega, A. Urban Waterfront Facing Integrated Coastal Management. Ocean. Coast. Manag. 2001, 44, 379-410.

35. Norcliffe, G.; Bassett, K.; Hoare, T. The Emergence of Postmodernism on the Urban Waterfront. J. Transp. Geogr. 1996, 4, 123-134.

36. Bassett, K.; Griffiths, R.; Smith, I. Testing Governance: Partnerships, Planning and Conflict in Waterfront Regeneration. Urban. Stud. 2002, 39, 1757-1775.

37. Lorente, J.P. Urban Cultural Policy and Urban Regeneration. The Special Case of Declining Port Cities-Liverpool, Marseilles, Bilbao. In Global Cultural Media, Arts, Policy, and Globalization; Crane, D., Kawasshima, N., Kawasaki, K., Eds.; Routledge: New York, NY, USA, 2002; pp. 93-104.

38. Rodwell, D. Planning Systems: Do They Fit the Current Needs of Historic Port Cities? In Proceedings of the International Conference on the Waterfront: Culture, Heritage and Regeneration of Port Cities, BT Convention Centre, Kings Waterfront, Liverpool, UK, 19-21 November 2008; pp. 19-21.

39. Tunbridge, J.; Ashworth, G. Leisure Resource Development in City Port Revitalization: The Tourist-Historic Dimension. In European Port Cities in Transition; Hoyle, B.S., Pinder, D.A., Eds.; Belhaven: London, UK, 1992; pp. 177-199.

40. Vayona, A. Investigating the Preferences of Individuals in Redeveloping Waterfronts: The Case of the Port of Thessaloniki-Greece. Cities 2011, 28, 424-432.

41. Gospodini, A. Urban Waterfront Redevelopment in Greek Cities: A Framework for Redesigning Space. Cities 2001, 18, 285-295.

42. Wood, R.; Handley, J. Urban Waterfront Regeneration in the Mersey Basin, North West England. J. Environ. Plan. Man. 1999, 42, 565-580.

43. Gordon, D. Planning, Design and Managing Change in Urban Waterfront Redevelopment. Town Plan. Rev. 1996, 67, 261-290.

44. Hoyle, B. Lamu-Waterfront Revitalization in an East African Port-City. Cities 2001, 18, 297-213. 
45. Miller, L. Sustainable Waterfront Revitalization: Baltimore, San Francisco, and Seattle. Master's Dissertation, Faculty of California Polytechnic State University, San Luis Obispo, CA, USA 2011.

46. Millspaugh, M. The Inner Harbor Story: A Model of Urban Waterfront Development, Baltimore's Inner Harbor Offers an Adventure in Downtown Revitalization. Urban Land 2003, April, 35-41.

47. Baltimore Inner Harbor Panorama from Federal Hill Park (overlooking the harbor). Available online: http://www.southbaltimore.com/InnerHarbor/baltimore_panorama.html (accessed on 19 March 2013).

48. Gospodini, A. Post-Industrial Trajectories of Mediterranean European Cities: The Case of Post-Olympics Athens. Urban. Stud. 2009, 46, 1157-1186.

49. Fagence, M. City Waterfront Redevelopment for Leisure, Recreation and Tourism. In Recreation and Tourism as a Catalyst for Urban Waterfront Redevelopment: An International Survey; Craig-Smith, S., Fagence, M., Eds.; Praeger: London, UK, 1995; pp. 135-157.

50. Evans, G.L.; Foord, J. Rich Mix Cities: From Multicultural Experience to Cosmopolitan Engagement. Ethnol. Eur. J. Eur. Ethnol. 2005, 34, 71-84.

51. Zukin, S. How to Create a Culture Capital: Reflections on Urban Markets and Places. In Century City: Art and Culture in the Modern Metropolis; Blazwick, I., Ed.; Tate Publishing: London, UK, 2001; pp. 259-264.

52. Landry, C. The Creative City: A Toolkit for Urban. Innovators; Earthscan: London, UK, 2000.

53. Evans, G.L. Hard Branding the Culture City_From Prado to Prada. Int. J. Urban. Reg. 2003, 27, $417-440$.

54. Evans, G. Creative Spaces, Tourism and the City. In Tourism, Creativity and Development; Richards, G., Wilson, J., Eds.; Routledge: Oxon, UK, 2007; pp. 57-72.

55. Florida, R. Cities and the Creative Class.; Routledge: New York, NY, USA, 2004.

56. Florida, R. The Flight of the Creative Class: The New Global Competition for Talent; Harper Business: New York, NY, USA, 2005.

57. Porter, M. The Competitive Advantage of the Inner City. Harv. Bus. Rev. 1995, 73(3), 53-71.

58. Porter, M. Clusters and the New Economics of Competition. Harv. Bus. Rev. 1998, 76(6), 77-90.

59. Marshall, A. Principles of Economics; Macmillan: London, UK, 1920.

60. Zukin, S. Postmodern Urban Landscapes: Mapping Culture and Power. In Modernity and Identity; Lash, S., Friedman, J., Eds.; Basil Blackwell: London, UK, 1992; pp. 221-247.

61. Mommaas, H. Cultural Clusters and the Post-Industrial City: Towards the Remapping of Urban Cultural Policy. Urban. Stud. 2004, 41, 507-532.

62. INFO. Available online: http://www.kaapelitehdas.fi/en/info (accessed on 15 March 2013).

63. Spike Island. Available online: http://www.spikeisland.org.uk/about-spike-island/ (accessed on 15 March 2013).

64. Evans, G.; Foord, J.; Gertler, M.; Tesolin, L.; Weinstock, S. Strategies for Creative Spaces and Cities: Lessons Learned. Available online: http://www.web.net/ imagineatoronto/Creative_Cities_ Lessons_Learned.pdf (accessed on 16 September 2013).

65. Lee, M. Relocating Location: Cultural Geography, the Specificity of Place and the City of Habitus. In Cultural Methodologies; McGuigan, J., Ed.; Sage: London, UK, 1997.

66. Beck, U. The Cosmopolitan Society and Its Enemies. Theor. Cult. Soc. 2002, 19, 17-44. 
67. Kirshenblatt-Gimblett, B. Destination Culture. Tourism, Museums and Heritage; University of California Press: Berkeley, CA, USA, 1998.

68. Campo, D. Brooklyn's Vernacular Waterfront. J. Urban. Des. 2002, 7, 171-199.

69. Edwards, D.; Griffin, T.; Hayllar, B. Urban Tourism Research: Developing an Agenda. Ann. Tourism Res. 2008, 35, 1032-1052.

70. Ashworth, G.J.; Tunbridge, J.E. The Tourist-Historic City; Belhaven: London, UK, 1990.

71. Hankinson, G. Location Branding: A study of the Branding Practices of 12 English Cities. J. Brand Manag. 2001, 9, 127-142.

72. Kavaratzis, M. From City Marketing to City Branding. J. Place Brand. 2004, 1, 58-73.

73. UNESCO. Towards Sustainable Strategies for Creative Tourism. In Discussion Report of the Planning Meeting for 2008 International Conference on Creative Tourism, Proceedings of the Creative Cities Network, Santa Fe, New Mexico, NM, USA, 25-27 October 2006.

74. Walberg, D. Political Party Boy. Daily Xtra, 23 November 2005. Available online: http://dailyxtra.com/canada/ideas/political-party-boy?market=210 (accessed on 29 September 2013).

75. Bonink, C.; Hitters, E. Creative Industries as Milieux of Innovation: the Westergasfabriek, Amsterdam. In Cultural Attractions and European Tourism; Richards, G., Ed.; Cabi Publishing: Wallingford, UK, 2001; pp. 227-240.

76. Rodwell, D. Conservation and Sustainability in Historic Cities; Blackwell Publishing: Oxford, UK, 2007.

77. Anderson, D.; Nurick, J. Cultural Impact: Measuring the Economic Effects of Culture. Locum Destin. Rev. 2002, 10, 15-17.

78. Rodwell, D.; van Oers, R. Summary Report of the Regional Conference of Countries of Eastern and Central Europe on "Management and Preservation of Historic Centers of Cities Inscribed on the World Heritage List”, St Petersburg, Russia, 29 January-2 February 2007; UNESCO: Paris, France, 2007. Available online: http://whc.unesco.org/uploads/activities/documents/activity-666-5.pdf (accessed on 22 May 2012).

(C) 2013 by the author; licensee MDPI, Basel, Switzerland. This article is an open access article distributed under the terms and conditions of the Creative Commons Attribution license (http://creativecommons.org/licenses/by/3.0/). 